Article

\title{
Machine Performance and Hog Fuel Quality Evaluation in Olive Tree Pruning Harvesting Conducted Using a Towed Shredder on Flat and Hilly Fields
}

\author{
Alessandro Suardi ${ }^{1}$ (D), Francesco Latterini ${ }^{1, *(D)}$, Vincenzo Alfano ${ }^{1}$ (D) Nadia Palmieri ${ }^{1}$ (D), \\ Simone Bergonzoli ${ }^{2}$ D, Emmanouil Karampinis ${ }^{3,4}\left(\mathbb{D}\right.$, Michael Alexandros Kougioumtzis ${ }^{3,4}$, \\ Panagiotis Grammelis ${ }^{3}$ and Luigi Pari ${ }^{1}$ (D) \\ 1 Consiglio per la Ricerca in Agricoltura e l'Analisi dell'Economia Agraria (CREA), Centro di Ricerca \\ Ingegneria e Trasformazioni Agroalimentari, Via della Pascolare 16, 00015 Monterotondo, RM, Italy; \\ alessandro.suardi@crea.gov.it (A.S.); vincenzo.alfano@crea.gov.it (V.A.); nadia.palmieri@crea.gov.it (N.P.); \\ luigi.pari@crea.gov.it (L.P.) \\ 2 Consiglio per la Ricerca in Agricoltura e l'Analisi dell'Economia Agraria (CREA), Centro di Ricerca \\ Ingegneria e Trasformazioni Agroalimentari, Via Milano, 43, 24047 Treviglio, BG, Italy; \\ simone.bergonzoli@crea.gov.it \\ 3 CERTH Centre for Research and Technology-Hellas, Egialias 52, GR 15125 Athens, Greece; \\ karampinis@certh.gr (E.K.); kougioumtzis@certh.gr (M.A.K.); grammelis@certh.gr (P.G.) \\ 4 Laboratory of Steam Boilers and Thermal Plants, Department of Mechanical Engineering, National Technical \\ University of Athens, Heroon Polytechniou 9, Zografou Campus, GR 15780 Athens, Greece \\ * Correspondence: francesco.latterini@crea.gov.it; Tel.: +39-06-9067-5248
}

Received: 15 March 2020; Accepted: 31 March 2020; Published: 3 April 2020

\begin{abstract}
Pruning residues from olive groves represent an important biomass source. Until now, the management of pruning residue has generally represented a disposal problem rather than an opportunity for additional revenue. The main problem is the lack of a well-organized pruning biomass supply chain. In particular, harvesting is a key stage that influences the product quality, the type of logistics chain, and the economic sustainability of the pruning supply chain. The aim of the present paper was the evaluation of the machine performance of the Facma Comby TR200 towed shredder. The harvesting tests took place in Agios Konstantinos, Fthiotida, Central Greece. Two different experimental fields were used for the evaluation of this harvesting system; these fields were characterized by different slopes to check the convenience of using such a towed shredder on both hilly slopes and flat terrains. Analysis was conducted focusing on both the work productivity and costs. Moreover, an evaluation of the obtained hog fuel quality was performed. The Facma Comby TR200 showed good work performances on both flat $\left(2.60 \mathrm{t}_{\mathrm{dm}} \cdot \mathrm{h}^{-1}\right)$ and hilly $\left(2.74 \mathrm{t}_{\mathrm{dm}} \cdot \mathrm{h}^{-1}\right)$ land, even if a consistent influence of the pruning biomass yield on the work performances was reported. The biomass quality could be consistently improved by modifying the pick-up systems to avoid the collection of inert materials (soil and rocks). In fact, the analysis showed a high ash content in the comminuted material ( $4 \%$ dry basis). Finally, the economic aspects of this study's results were in line with those reported in the literature. The applied harvesting system showed a cost equal to 29.88 and $16.59 € \cdot \mathrm{tfm}_{\mathrm{fm}}{ }^{-1}$ on flat and hilly land, respectively.
\end{abstract}

Keywords: pruning harvesting; olive groves; biomass quality; slope; work productivity 


\section{Introduction}

Olive tree groves are a distinctive feature of the Mediterranean landscape, and in Europe they represent the ancestral crops of countries such as Italy, Greece, and Spain. wherein these countries olive oil production has represented an export-oriented industrial activity for at least two millennia [1]. Considering the large amount of pruning residues that derive from olive groves' maintenance, these could be important sources of biomass, akin to pruning residues from other crops [2-7]. However, until now, the management of pruning residue has generally represented a disposal problem rather than an opportunity for additional revenue, even if its potential has already been stated [8-10].

The main problem is the lack of a well-organized pruning biomass supply chain, a situation that is common all over Europe [11,12].

In most of Europe, the largest pieces of pruned wood, i.e., over $50 \mathrm{~mm}$ in diameter, are used for firewood [13]. Small branches and shoots, which instead could be very important for energy production, are usually removed from the orchard using a tractor with a fork or manually piled up, and then disposed of or burned, with consequent negative economic and/or environmental impacts. An alternative is that pruning residues are mulched and left on the ground and/or incorporated into the soil [11]. One possible solution to this problem under a bio-Economy point of view is the demonstration of the feasibility of integrated biomass logistics centers (IBLCs) [14]. IBLCs are business strategies designed to allow agro-industries to link to the growing bio-based economy by "taking advantage of unexploited synergies," such as facilities and personnel, as well as inputs (e.g., local unexploited agricultural residues, such as prunings) and outputs [15]. The EU project AGROinLOG aims to involve the agrarian sector in the supply of solid biofuels in Europe. AGROinLOG activities in Greece were properly aimed at the development of an IBLC for the use of olive tree pruning residues for energy purposes. Dealing with the development of pruning supply chain harvesting is a key stage that influences the product quality, the type of logistics chain, and the economic sustainability [13]. For this reason, in recent years, manufacturers of agricultural equipment have focused their attention on the development of pruning residue management systems that offer different solutions based mainly on shredding and baling technologies [16]. Shredding machines generally derive from conventional mulchers equipped with a storage bin or with a blower, where the latter is designed to direct the flow of comminuted residue to an accompanying trailer. Such implements are relatively cheap and are designed for being towed or carried by farm tractors in the 50-70 $\mathrm{kW}$ class [8].

The evaluation of various machines' performance in pruning residues harvesting is a critical aspect for the implementation of biomass value chains $[17,18]$. Except for aspects related to the physic-chemical features of the biomass, comminuting and storage have a strong influence on other important variables, such as the amount of contaminants (soil, stones), particle size, and bulk density. Biomass losses and contamination are clearly related to the setting of the pick-up system. Low-lying pick-up mechanisms lead to lower harvesting losses but increase the inlet of soil particles to the detriment of biofuel quality $[13,19]$. Moreover, the shape, size, number, and type of comminuting devices, as well as the machine settings, can substantially affect the biomass quality [20-23]. An incorrect comminuting can lead to major problems with the wood fuel, for example high dry matter losses, high ash content, reduction in energy value, and self-ignition $[24,25]$. The particle size distribution of woody biomass plays a key role in the production of high-grade fuel because it is directly linked to the bulk density, the storage behavior, and the transport costs, moreover it can also create difficulties with fuel feeding at the combustion plant. The usage of a wrong machine can lead to uneven-sized chips with a significant percentage of oversized or undersized particles, and any attempt to decrease one class could lead to an undesirable increase in the other, even with the application of refining devices [19,26-28]. Based on the previous discussion, the aim of the present study was the evaluation of the machine performance of the Facma Comby TR200 towed shredder (Facma srl, Vitorchiano, Lazio, Italy).

For this paper, the Facma Comby TR200 performance was analyzed in two different experimental fields characterized by different slopes. This allowed for determining the possibility of using such a towed shredder in both hilly and flat terrains. 
Analysis was conducted by focusing on the work productivity, obtained biomass quality, and harvesting costs. There is not much information in the literature about the harvesting behavior of this machine on hilly land; this is an issue because a comparison of the performance and fuel consumption of the machine in different field conditions is useful for clarifying the convenience of its use for the local farmers and the implementation of a new pruning supply chain. Moreover, an evaluation of the obtained biomass was conducted to evaluate the market possibilities of the olive tree prunings as hog fuel. Finally, interviews were conducted with some Italian enterprises and cooperatives involved in wood chips and hog fuel production to better understand the characteristics of the hog fuel market and hence illustrate to the reader the possible solutions and practical adjustments for the development of hog fuel from the pruning residues value chain. Considering the absence of a hog fuel or wood chip market in Greece, the study referred to the Central and South Italy context, which is very similar to the Greek one for olive grove distribution and importance.

\section{Materials and Methods}

The applied research procedure, which is described in detail in the subsequent paragraphs, is summarized in Figure 1.

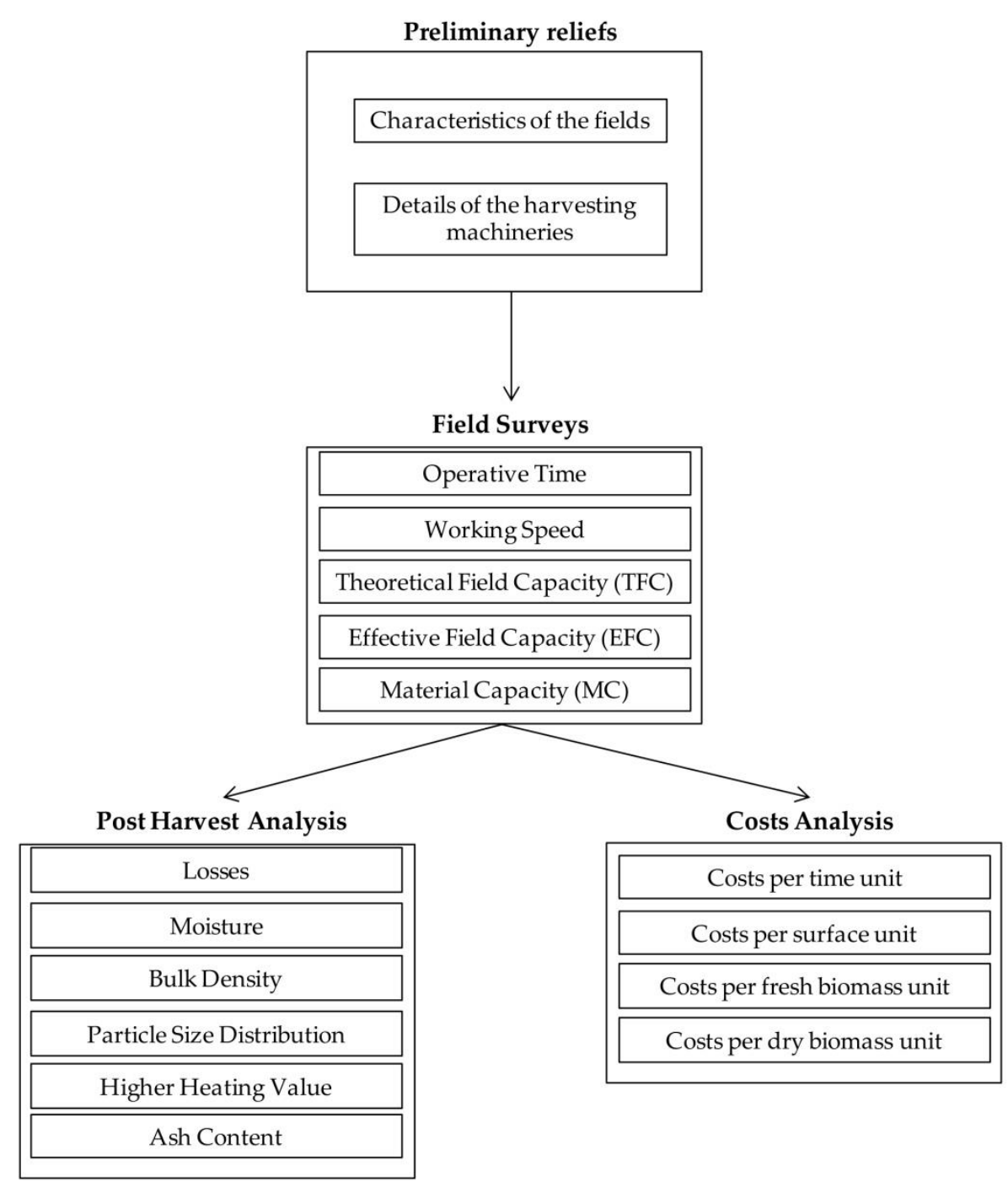

Figure 1. Graphical block diagram of the research procedure. 


\subsection{Study Area}

Agios Konstantinos' agriculture depends mainly on olive tree production. Agios Konstantinos has around 750 ha [29] of olive groves, with more than 160,000 olive trees, producing two main edible olive varieties (Kalamon and Amfissis). The vast majority (80-90\%) of the trees belong to the Amfissis variety. It is considered a very productive variety but is quite susceptible to diseases. Olive farmers in Agios Konstantinos prune their olive trees once every year. In comparison with other olive areas in Greece, Agios Konstantinos has olive groves with a high biomass productivity [30]. The current common practice used to manage olive prunings in Agios Konstantinos is mainly burning them in open fires inside the olive groves, or less frequently, mulching them on the soil. Thus, the investigation of harvesting solutions for untapped biomass sources, such as olive tree prunings, is of high significance.

Two experimental fields were selected in Agios Konstantinos, Fthiotida (NUTS3), one characterized by a flat slope and the other by a hilly slope. The study area location is shown in Figure 1. In the following paragraphs of the paper, the flat slope field is indicated with "FL" and the hilly field is indicated with "HL."

Details of the two experimental fields are given in Table 1.

Table 1. Main characteristics of the olive groves.

\begin{tabular}{cccc}
\hline Characteristic & Unit & Flat Slope (FL) & Hilly Slope (HL) \\
\hline Surface & ha & 0.6 & 1.67 \\
Exposition & $\%$ & - & Northwest \\
Prevalent Slope & $\% .50$ & 19.70 \\
Minimum Slope & $\%$ & 1.50 & 15.80 \\
Maximum Slope & $\%$ & 3.60 & 21.80 \\
Layout (Width between rows $\times$ distance between trees) & $\mathrm{m} \times \mathrm{m}$ & $10 \times 10$ & $10 \times 10$ \\
Olive variety & & Amfissis & Amfissis \\
Number of olive trees & & 76 & 175 \\
Average pruning $\varnothing$ & $\mathrm{cm}$ & 3 & 3 \\
Average pruning lenght & $\mathrm{cm}$ & 204 & 215 \\
Average windrow width & $\mathrm{cm}$ & 140 & 162 \\
Average windrow height & $\mathrm{cm}$ & 55 & 55 \\
\hline
\end{tabular}

As shown in Table 1 and Figure 2, besides the different slope, there were no substantial differences between the two olive groves regarding the planting patterns and main characteristics of the residues (diameter and length of the branches).
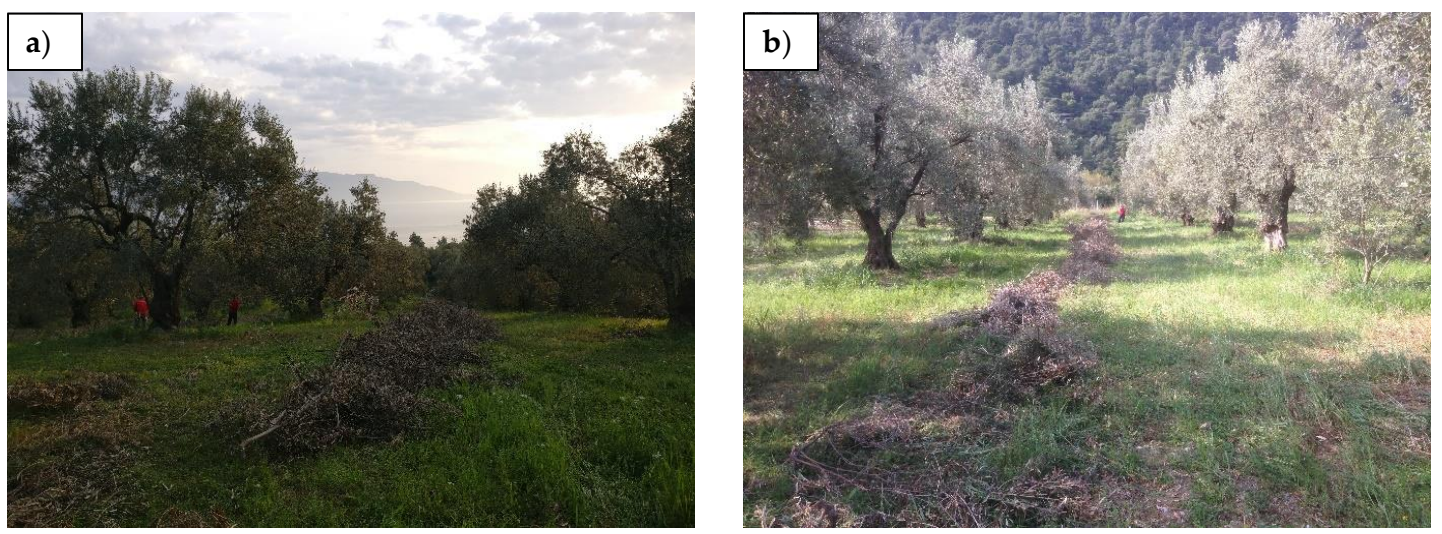

Figure 2. (a) Windrows on the flat slope field. (b) Windrows on the hilly slope field. 


\subsection{Harvesting System Description}

Before pruning harvesting, a preliminary windrowing step is usually necessary. This can be performed either manually or with a raking machine. In this work, windrowing for both the flat and hilly olive groves was conducted using an ABIMAC-rake-modified Girolivo (Abimas srl., Savigliano, Piemonte, Italy) powered by a 44 kW Ford 4610 tractor (Ford Motor Company spa, Dearborn, MI, USA).

The tractor used to power the Facma Comby TR200 (Figure 3) was instead an Ebro Model 85 (96 kW) (Ebro, Barcelona, Catalonia, Spain). The Facma Comby TR200 consisted of a towed shredder with a $2 \mathrm{~m}$ working width. The machine was composed of a pick-up system located on the front of the machine, a horizontal rotor for biomass comminuting that was able to work biomass to an $8 \mathrm{~cm}$ diameter, a metallic grid located between the rotor and the dumpster with the function of filtering biomass according to a desired size, and a rear dumpster of $5 \mathrm{~m}^{3}$ for comminuted the biomass collection. The machine was $3.72 \mathrm{~m}$ long, $1.80 \mathrm{~m}$ high, and weighed $2200 \mathrm{~kg}$. According to the manufacturer, the Facma Comby TR200 needs to be towed by a tractor of at least $56 \mathrm{~kW}(75 \mathrm{hp})$. Therefore, it is important to underline that the tractor used in the tests was substantially oversized.

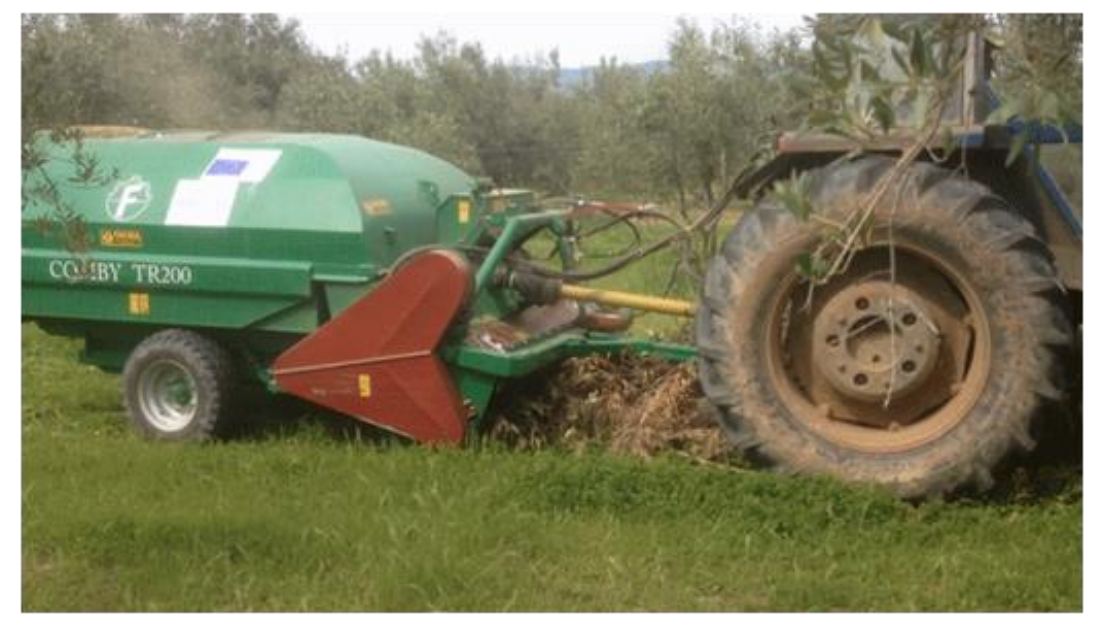

Figure 3. The Facma Comby TR200.

\subsection{Data Collection}

\subsubsection{Field Work Evaluation}

In each experimental field, the performance of the machines was evaluated through the study of the working times according to the standards ASAE S495 DEC99 [31]. The working times were measured and used to determine the actual and theoretical amount of area that could be served per unit time by the machine. These were termed the effective field capacity (EFC) $\left(\right.$ ha $\cdot \mathrm{h}^{-1}$ ) and the theoretical field capacity (TFC) $\left(h a \cdot h^{-1}\right)$, respectively. The EFC was also computed by dividing the hectares processed by the operative time (OT), i.e., the raw time needed to complete the harvest, including accessory times. These accessory times included the turning times, namely the time needed for maintenance, regulations, refueling, and unloading the dumpster. The TFC is the theoretical maximum field capacity without the accessory times. Lastly, the material capacity (MC) was computed as the quantity of pruning harvested per unit time $\left(\mathrm{t} \cdot \mathrm{h}^{-1}\right)$.

The fuel consumption was determined through machine tank refilling until a full level was achieved at the end of each experimental unit using large, graduated cylinders to define the volume of fuel consumed (L·ha ${ }^{-1}$ or L $\cdot \mathrm{t}^{-1}$ of biomass harvested).

\subsubsection{Post Harvest Measurements and Data Analysis}

Other important parameters were evaluated after the end of the harvesting operation. 
After the harvesting, the biomass collected was weighed using a farm scale to determine the yield of biomass $\left(\mathrm{t}_{\mathrm{fm}} \cdot \mathrm{ha}^{-1}\right)$.

After the harvesting phase, the harvesting loss (\%) was assessed using three transects per experimental field (large like the width of the harvester per $5 \mathrm{~m}$ long) that were randomly identified along the rows. All the biomass left on the ground inside the transects was collected by hand and weighed in the field using a dynamometer. Therefore, the area of each transect was normalized relative to a one-hectare surface to determine the amount of biomass left on the ground and not collected.

Five samples of $500 \mathrm{~g}$ of comminuted product were collected per experimental field to determine the moisture content (\%) in accordance with EN ISO 18134-2:2017 [32]. The bulk density $\left(\mathrm{kg} \cdot \mathrm{m}^{-3}\right)$ was determined in both experimental fields in accordance with ISO 17828:2015 [33].

Furthermore, five samples of comminuted product of $500 \mathrm{~g}$ each were collected from a pile of mixed material collected from the two experimental fields to characterize the hog fuel regarding the particle size distribution analysis in accordance with the International Standard EN ISO 17225-4:2014 [34]. Samples of each field were retrieved and analyzed in CERTH/CPERI's laboratories in Ptolemaida by applying the established standards to determine the ash content (\%) according to EN ISO 18122 [35] and the higher heating value (HHV, MJ.kg ${ }^{-1}$ ) according to EN ISO 18125 [36] by using a Parr 6200 Calorimeter (Parr Instrument Company, Moline, IL, USA).

Statistical analysis was conducted using ANOVA and Tukey's HSD test.

\subsection{Cost Analysis}

The economic analysis focused on both ownership and operating costs in accordance with the parameters measured during the field tests (primary data) or by using standard values provided by the Centro Ricerca per le Produzioni Animali (CRPA) methodology [37]. The main economic parameters used for the machine operating costs analysis are reported in Table 2.

Table 2. Main economic parameters used for the economic analysis.

\begin{tabular}{cccccc}
\hline Parameters & Unit & Facma Comby TR200 & Ford 4610 & Ebro Model 85 & Abimac Girolivo \\
\hline Investment & $€$ & $21,000.00$ & $38,690.00$ & $80,166.00$ & $12,900.00$ \\
Service life & $\mathrm{yr}$ & 10 & 10 & 10 & 10 \\
Usage & $\mathrm{h} \cdot \mathrm{yr}^{-1}$ & 460 & 460 & 460 & 460 \\
Labour cost & $€ \cdot \mathrm{h}^{-1}$ & & 11.50 & 11.50 & \\
Workers & $\mathrm{n}$ & & 1 & 1 & \\
\hline
\end{tabular}

\section{Results}

\subsection{Machine Performance and Quality of the Woody Comminuted Product}

Regarding the work performance of the raking phase, for FL and HL, no significant differences in the field capacity and fuel consumption were found. The shredding phase also showed no significant differences in hilly and flat lands regarding the fuel consumption and harvesting losses of biomass. On the other hand, substantial differences were found regarding field capacities and working speed, which were higher for FL. However, the amount of biomass collected from HL was significantly higher than from FL, though the material capacity $\left(\mathrm{t}_{\mathrm{fm}} \cdot \mathrm{h}^{-1}\right)$ between the two treatments did not vary.

Focusing on the obtained biomass quality, the moisture content was similar from both FL and HL with an average value of $27 \%$. Similar results were found for the bulk density, with no statistically significant differences between the FL and HL values. Detailed results of the machine performance and hog fuel characteristics are reported in Table 3. 
Table 3. Results of the statistical analysis regarding the machine performance of a pruning harvesting system on flat and hilly slopes and regarding hog fuel characteristics.

\begin{tabular}{|c|c|c|c|c|c|}
\hline Machine Performance & Unit & $\begin{array}{l}\text { Pruning Rake } \\
\text { (FL) }\end{array}$ & $\begin{array}{c}\text { Pruning Rake } \\
\text { (HL) }\end{array}$ & $\begin{array}{c}\text { Facma Comby } \\
\text { TR200 (FL) }\end{array}$ & $\begin{array}{l}\text { Facma Comby } \\
\text { TR200 (HL) }\end{array}$ \\
\hline Theoretical Field capacity & $h a \cdot h^{-1}$ & 1.13 & 1.57 & $2.98 \pm 0.39 *$ & $1.56 \pm 0.10 *$ \\
\hline Effective Field capacity & $h a \cdot h^{-1}$ & 0.60 & 0.88 & $1.57 \pm 0.16^{*}$ & $0.79 \pm 0.21 *$ \\
\hline Field efficiency & $\%$ & 0.53 & 0.56 & $0.52 \pm 0.70$ & $0.51 \pm 0.12$ \\
\hline Working speed & $\mathrm{km} \cdot \mathrm{h}^{-1}$ & - & - & $3.85 \pm 0.57$ * & $1.94 \pm 0.13 *$ \\
\hline Biomass yield & $\mathrm{t}_{\mathrm{fm}} \cdot \mathrm{ha}^{-1}$ & - & - & $2.29 \pm 0.54$ * & $5.01 \pm 1.61 *$ \\
\hline Biomass yield & $\mathrm{t}_{\mathrm{dm}} \cdot \mathrm{ha}^{-1}$ & & & $1.67 \pm 0.38$ * & $3.66 \pm 1.13 *$ \\
\hline Material capacity & $t_{\mathrm{fm}} \cdot \mathrm{h}^{-1}$ & - & - & $3.56 \pm 0.68$ & $3.75 \pm 0.44$ \\
\hline Material capacity & $t_{d m} \cdot h^{-1}$ & - & - & $2.60 \pm 0.50$ & $2.74 \pm 0.32$ \\
\hline Losses & $\%$ & - & - & $23 \pm 12$ & $27 \pm 7$ \\
\hline Fuel consumption & $\mathrm{L} \cdot \mathrm{ha}^{-1}$ & 3.01 & 2.11 & $8.1 \pm 0.3$ & $18.5 \pm 3.9$ \\
\hline Fuel consumption & $\mathrm{L} \cdot \mathrm{t}_{\mathrm{fm}}-1$ & 0.74 & 0.75 & $3.7 \pm 0.7$ & $3.8 \pm 0.8$ \\
\hline Fuel consumption & $\mathrm{L} \cdot \mathrm{t}_{\mathrm{dm}}-1$ & 1.01 & 1.03 & $5.1 \pm 1.0$ & $5.2 \pm 1.1$ \\
\hline Fuel consumption & $L \cdot h^{-1}$ & 1.81 & 1.85 & $12.7 \pm 0.8$ & $14.2 \pm 1.7$ \\
\hline Hog Fuel Characteristics & Unit & $\begin{array}{l}\text { Pruning Rake } \\
\text { (FL) }\end{array}$ & $\begin{array}{l}\text { Pruning Rake } \\
\text { (HL) }\end{array}$ & $\begin{array}{l}\text { Facma Comby } \\
\text { TR200 (FL) }\end{array}$ & $\begin{array}{l}\text { Facma Comby } \\
\text { TR200 (HL) }\end{array}$ \\
\hline Bulk density & $\mathrm{kg} \cdot \mathrm{m}^{-3}$ & - & - & $229 \pm 8$ & $224 \pm 14$ \\
\hline Moisture content & $\%$, w.b. & - & - & $27.3 \pm 1.39$ & $27.8 \pm 1.42$ \\
\hline Ash content & $\%$, d.b. & - & - & $4.00 \pm 0.11$ & $4.20 \pm 0.19$ \\
\hline Higher heating value & $\begin{array}{l}\text { MJ.kg }{ }^{-1} \\
\text { d.b. }\end{array}$ & - & - & 19.58 & 20.27 \\
\hline
\end{tabular}

w.b.: wet basis, d.b.: dry basis; ${ }^{*} p<0.05,{ }^{* *} p<0.01$ (procedure: Tukey's HSD method).

The particle size distribution (PSD) analysis showed that the hog fuel produced using the Facma Comby TR200 belonged to the particle size class P16 (60\% of the product with particles between 3.15 and $16 \mathrm{~mm}$ ) and a fine fraction class F15 (fine fraction $<15 \%$ ), and the d50 value (median value of the cumulated distribution curve) was $11.13 \mathrm{~mm}$. Details of the particle size distribution analysis are given in Table 4.

Table 4. Particle size distribution (PSD) of the Facma Comby TR200 hog fuel.

\begin{tabular}{ccc}
\hline Particle Size & PSD & Cumulative Distribution \\
\hline$[\mathrm{mm}]$ & {$[\%]$} & {$[\%]$} \\
\hline$<3.15 \mathrm{~mm}$ & 12 & 12.00 \\
$3-15-8 \mathrm{~mm}$ & 27.69 & 39.69 \\
$8-16 \mathrm{~mm}$ & 26.37 & 66.06 \\
$16-45 \mathrm{~mm}$ & 17.53 & 83.59 \\
$45-63 \mathrm{~mm}$ & 0.59 & 84.18 \\
$>63 \mathrm{~mm}$ & 15.82 & 100.00 \\
\hline
\end{tabular}

\subsection{Cost Analysis}

A detailed view of the costs for both experimental fields subdivided into fixed and variable costs for each machine is given in Table 5 . The two tractors were the most economically impactful machines on the overall harvesting system's costs. In fact, about $85 \%$ of the harvesting system's costs in both experimental fields were linked to those of the two tractors (Ebro Model 85 and Ford 4610), while only $15 \%$ were related to the towed shredder and the rake. 
Table 5. Details of the fixed and variable costs for each machine used in both experimental fields.

\begin{tabular}{|c|c|c|c|c|c|c|c|c|c|c|}
\hline & \multirow{2}{*}{ Cost Item } & \multirow{2}{*}{ Measure Unit } & \multicolumn{2}{|c|}{ Facma Comby TR200 } & \multicolumn{2}{|c|}{ Ebro Model 85} & \multicolumn{2}{|c|}{ Ford 4610} & \multicolumn{2}{|c|}{ Abimac Girolivo } \\
\hline & & & FL & HL & FL & HL & FL & HL & FL & HL \\
\hline \multirow{7}{*}{ 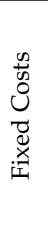 } & Reintegration quote & $€ \cdot \mathrm{yr}^{-1}$ & 1728.63 & 1728.63 & 5355.73 & 5355.73 & 2584.80 & 2584.80 & 1033.66 & 1033.66 \\
\hline & Interests & $€ \cdot \mathrm{yr}^{-1}$ & 370.71 & 370.71 & 1601.62 & 1601.62 & 772.98 & 772.98 & 231.95 & 231.95 \\
\hline & Shelter & $€ \cdot \mathrm{yr}^{-1}$ & 17.11 & 17.11 & 15.06 & 15.06 & 13.66 & 13.66 & 4.00 & 4.00 \\
\hline & Insurance & $€ \cdot \mathrm{yr}^{-1}$ & 52.50 & 52.50 & 200.42 & 200.42 & 96.73 & 96.73 & 32.25 & 32.25 \\
\hline & Miscellaneous expenses & $€ \cdot \mathrm{yr}^{-1}$ & 69.61 & 69.61 & 215.47 & 215.47 & 110.38 & 110.38 & 36.25 & 36.25 \\
\hline & Total fixed cost per year & $€ \cdot \mathrm{yr}^{-1}$ & 2168.95 & 2168.95 & 7172.82 & 7172.82 & 3468.16 & 3468.16 & 1301.86 & 1301.86 \\
\hline & Total fixed cost per hour & $€ \cdot h^{-1}$ & 4.72 & 4.72 & 15.59 & 15.59 & 7.54 & 7.54 & 2.83 & 2.83 \\
\hline \multirow{9}{*}{ 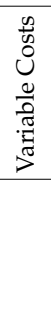 } & Maintenance & $€ \cdot h^{-1}$ & 1.68 & 1.68 & 1.51 & 1.51 & 0.73 & 0.73 & 1.03 & 1.03 \\
\hline & Fuel & $€ \cdot h^{-1}$ & - & - & 7.29 & 8.15 & 1.04 & 1.06 & - & - \\
\hline & Lubricant & $€ \cdot h^{-1}$ & - & - & 0.24 & 0.24 & 0.14 & 0.14 & - & - \\
\hline & Manpower & $€ \cdot h^{-1}$ & - & - & 11.50 & 11.50 & 11.50 & 11.50 & - & - \\
\hline & Total variable cost per hour & $€ \cdot h^{-1}$ & 1.68 & 1.68 & 20.53 & 21.39 & 13.41 & 13.43 & 1.03 & 1.03 \\
\hline & Total cos & $€ \cdot \mathrm{yr}^{-1}$ & 2940.41 & 2940.41 & 16617.50 & 17013.56 & 9635.72 & 9646.28 & 1775.76 & 1775.76 \\
\hline & Total cost per hour & $€ \cdot h^{-1}$ & 6.39 & 6.39 & 36.13 & 36.99 & 20.95 & 20.97 & 3.86 & 3.86 \\
\hline & Total cost per hectare & $€ \cdot \mathrm{ha}^{-1}$ & 4.07 & 8.09 & 23.01 & 46.82 & 34.91 & 23.83 & 6.43 & 4.39 \\
\hline & Total cost per ton & $€ \cdot t_{\mathrm{fm}}{ }^{-1}$ & 1.78 & 1.62 & 10.05 & 9.34 & 15.25 & 4.76 & 2.81 & 0.88 \\
\hline
\end{tabular}

A summary of the various costs is also reported in Table 6. Table 6 and Figure 4 show that the systems' costs per unit time ( $\left.€ \cdot \mathrm{h}^{-1}\right)$ were very similar for both FL and HL after considering the raking operation and taking into consideration only the shredder's costs.

Table 6. Cost analysis results regarding the FL and HL experimental fields. "Harvesting Operation" refers to the costs of the Facma Comby TR200 and Ebro Model 85 tractors, while "Harvesting + Raking Operations" refers to the overall harvesting system's costs, i.e., the Facma Comby TR200, Ebro Model 85 tractor, Ford 4610 tractor, and Abimac Girolivo rake. FM: fresh matter, DM: dry matter.

\begin{tabular}{cccccc}
\hline \multirow{2}{*}{ Harvesting Cost } & \multirow{2}{*}{ Unit } & \multicolumn{2}{c}{ Harvesting Operation } & \multicolumn{2}{c}{ Harvesting + Raking Operations } \\
\cline { 3 - 5 } & & FL & HL & FL & HL \\
\hline Hourly cost & $€ \cdot \mathrm{h}^{-1}$ & 42.52 & 43.38 & 67.32 & 68.21 \\
Cost per unit area & $€ \cdot \mathrm{ha}^{-1}$ & 27.08 & 54.91 & 68.43 & 83.13 \\
Cost per product unit (FM) & $€ \cdot \mathrm{t}_{\mathrm{fm}}{ }^{-1}$ & 11.83 & 10.96 & 29.88 & 16.59 \\
Cost per product unit (DM) & $€ \cdot \mathrm{t}_{\mathrm{dm}}{ }^{-1}$ & 16.27 & 15.18 & 41.10 & 22.98 \\
\hline
\end{tabular}
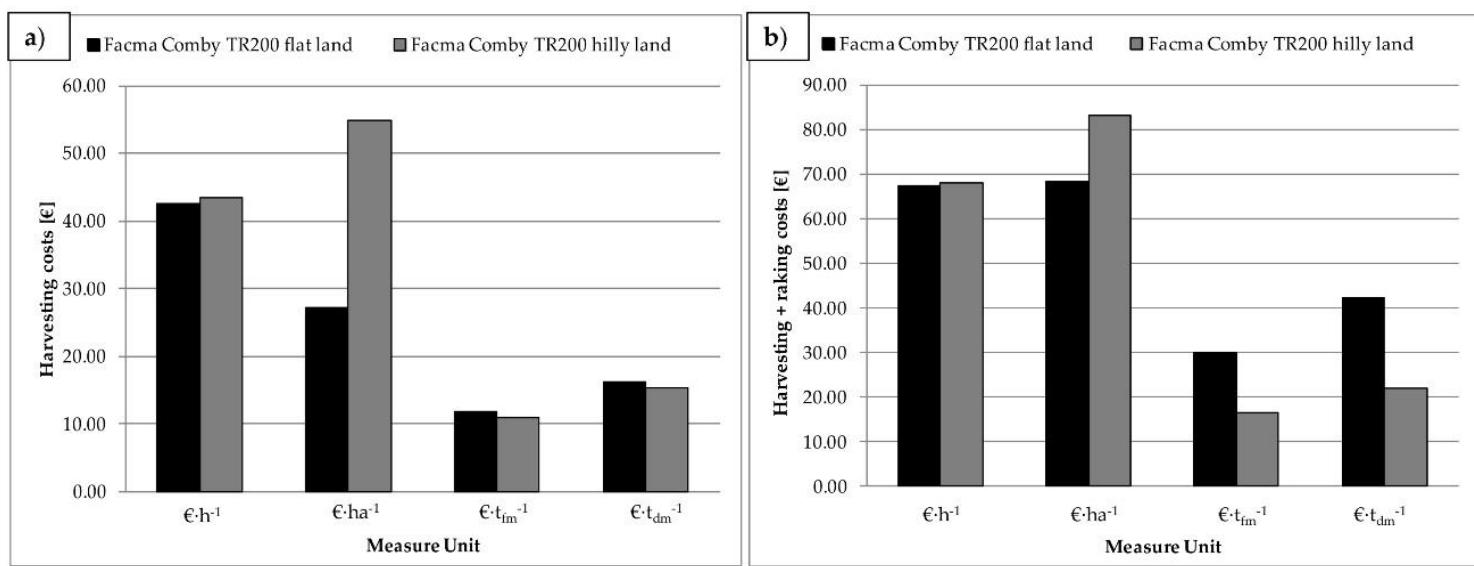

Figure 4. (a) Cost analysis regarding only the harvesting operation with the Facma Comby TR2000 towed shredder. (b) Cost analysis also considering the preliminary raking operation.

Regarding the systems' costs per surface unit area $\left(€ \cdot \mathrm{ha}^{-1}\right)$, there were substantial differences mostly when considering only the shredding operation. In particular, the flat slope experimental field incurred a lower cost than the hilly slope due to the lower field capacity of the latter. 
Finally, regarding the costs per fresh biomass unit $\left(€ \cdot t_{\mathrm{fm}}{ }^{-1}\right)$, the analysis showed very similar values for when concerning only the shredding costs. On the other hand, there were important differences between the two experimental fields when considering the overall system's costs (shredding + raking), with HL incurring substantially lower costs than FL. As expected, the trend regarding costs per dry biomass unit $\left(€ \cdot \mathrm{t}_{\mathrm{dm}}{ }^{-1}\right)$ was the same (Table 6$)$.

\section{Discussion}

\subsection{Machine Performance and Quality of the Work and Woody Comminuted Product}

The shredding and raking field efficiencies for FL and HL were similar. However, the field capacity of the shredding phase for HL was significantly lower than for FL; this was mainly due to the higher amount of biomass available in the hilly field ( $2.72 \mathrm{t} \mathrm{fm}_{\mathrm{m}} \cdot \mathrm{ha}^{-1}$ more biomass than in $\left.\mathrm{HL}\right)$, which required more time to be comminuted. It should be highlighted that the field capacity of the machines was influenced by several factors, including the shape of the field, the difficulty in turning, the necessary maintenance in the field, and the time for unloading of the product. However, the material capacity, i.e., the amount of biomass shredded per time unit, was practically the same in both fields (no significant statistical differences); therefore, the performance of the shredder did not change due to its use on the hill.

Consequently, significant differences were found in terms of the working speed, but no differences were observed in the fuel consumed (liter of diesel per hour, and liter per ton of woodchip produced, i.e., $L \cdot h^{-1}$ and $\left.L \cdot t^{-1}\right)$. On the flatland, the machine achieved a speed that was twice that on the hills because the pruning to be chipped was in lower quantities. Although a higher speed usually corresponds to a higher fuel consumption, it was evident that the greater fuel consumption on the hill $\left(\mathrm{L} \cdot \mathrm{ha}^{-1}\right.$ ) (where the machine worked more slowly) was linked not so much to the movement of the machine itself, but rather to the greater amount of pruning to be processed. In fact, by considering the fuel consumption per ton of product harvested $\left(\mathrm{L} \cdot \mathrm{t}^{-1}\right)$, as well as the hourly fuel consumption $\left(\mathrm{L} \cdot \mathrm{h}^{-1}\right)$, there was no statistically significant difference between the hilly and flat lands.

To explain this phenomenon, it should be added that the test conducted on the hilly land was carried out both uphill (with an increasing effort due to the progressive accumulation of material collected in the container) and downhill (with fuel savings due to utilizing the potential energy of the system and the theoretical zero fuel consumption), which led to a balance of fuel consumption regarding the movement of the tractor-shredder system. Therefore, even if the slope of about $20 \%$ measured for the hilly land was starting to be burdensome for the tractor, the overall results showed a slight increase in fuel consumption for the hill $\left(14.2 \mathrm{~L} \cdot \mathrm{h}^{-1}\right.$ on the hill compared to $12.7 \mathrm{~L} \cdot \mathrm{h}^{-1}$ on flat land), but this difference was not statistically significant (Table 3).

No statistically significant differences were found between the bulk density of the hog fuel produced on the two different experimental fields. Therefore, it seems that the lower working speed of the machine in the hilly field did not consistently affect this parameter.

Regarding the harvesting losses, which showed values of about $25 \%$ for both FL and HL, these were mostly linked to the windrow width, which at some point, became larger than the pick-up system of the shredder machine. This aspect could be improved through the higher compaction of the windrow during the raking phase to reduce the windrow width, or by applying swath brushes on both sides of the shredder pick-up system to facilitate the compaction of the swath at the feeding system of the shredder and thus increasing the harvesting efficiency and reducing the losses. These would improve the compaction of the pruning windrow, reducing the number of branches that escape the collection system.

Regarding the particle size distribution, the hog fuel produced belonged to the particle size class P16.5. The main problem with the obtained product regarding the fuel quality assessment was the consistent amount of oversized chips (15.82\%), which could represent a problem for both industrial and domestic plants. 
Regarding the physico-chemical properties of the obtained hog fuel, it was possible to make comparisons with the research of Picchi et al. [38], who analyzed hog fuels from different tree species pruning's residues, including olive trees. In particular, the ash content in the present study was very similar to Pichi et al. [38] (4.00\% vs. 3.70\%), but the HHV showed higher values: $19.53 \mathrm{MJ} \mathrm{kg}^{-1}$ vs. $17.51 \mathrm{MJ} \mathrm{kg}^{-1}$.

The consistent ash content was probably linked to the collection of soil and rocks, together with biomass within the machine shredding system. Such contamination was unavoidable when raking using mechanical pruning harvesting but could be decreased by adjusting the pick-up system height and by inserting dedicated screens [38]. Especially for olive tree prunings, the presence of leaves that have not fallen from the branches before or during harvesting is another factor that negatively influences the ash content.

By analyzing other previous studies that investigated olive trees' pruning harvesting performed with other machines-namely a $150 \mathrm{~kW}$, self-propelled Favaretto Speedy cut (Favaretto Paolo, Meolo, Veneto, Italy) [8]; a self-propelled SAT-4 (Valoriza Energia-Energy Agency, Villanueva de Algaidas, Andalusia, Spain) [39]; and a tractor-mounted Jordan (Jensen Service GmbH, Maasbüll, Schleswig-Holstein, Germany) powered using a $162 \mathrm{~kW}$ tractor [8] - it was found that the Facma Comby TR200 showed a higher effective field capacity on both FL $\left(1.57 \mathrm{ha} \cdot \mathrm{h}^{-1}\right)$ and HL $\left(0.79 \mathrm{ha} \cdot \mathrm{h}^{-1}\right)$ than both the Favaretto $\left(0.39 \mathrm{ha} \cdot \mathrm{h}^{-1}\right)$ and Jordan $\left(0.60 \mathrm{ha} \cdot \mathrm{h}^{-1}\right)$; in contrast, the SAT-4 showed a higher value of $3.37 \mathrm{ha} \cdot \mathrm{h}^{-1}$.

The Facma Comby TR200 also showed a better performance when compared with the field capacity obtained using a Serrat mod. Olipack T1800 $\left(0.78 \mathrm{ha} \cdot \mathrm{h}^{-1}\right)$ (Serrat, Castejón del Puente, Huesca, Spain) and a Berti mod. Picker C180 $\left(0.85 \mathrm{ha} \cdot \mathrm{h}^{-1}\right)$ (Berti, Caldiero, Veneto, Italy) towed shredders tested by Velazquez-Martı et al. [40]. Among the few studies available in the literature regarding olive prunings' harvesting using a towed chipper, the results obtained by Assirelli et al. [41] with a Tierre mod. Plano (Tierre Group srl, Curtarolo, Veneto, Italy) should be mentioned, where they recorded a field capacity of $0.85 \mathrm{ha} \cdot \mathrm{h}^{-1}$ and a very high material capacity equal to $11 \mathrm{t} \cdot \mathrm{h}^{-1}$ [13].

Regarding the material capacity $\left(\mathrm{t}_{\mathrm{fm}} \cdot \mathrm{h}^{-1}\right)$, the Facma Comby TR200 showed better values than the Serrat mod. Olipack T1800 $\left(1.38 \mathrm{t} \cdot \mathrm{h}^{-1}\right)$ and Berti mod. Picker C180 $\left(1.26 \mathrm{t} \cdot \mathrm{h}^{-1}\right)$ shredding machines recorded by Velazquez-Martı et al. [40], and a Nobili mod. TRP-RT $145\left(0.53 \mathrm{t} \cdot \mathrm{h}^{-1}\right)$ (Nobili, Molinella, Emilia-Romagna, Italy) shredding machine tested by Recchia et al. [42], both for FL $\left(3.56 \mathrm{t}_{\mathrm{fm}} \cdot \mathrm{h}^{-1}\right)$ and HL $\left(3.75 \mathrm{t}_{\mathrm{fm}} \cdot \mathrm{h}^{-1}\right)$. Furthermore, the chippers Promagri mod. $2000\left(1.36 \mathrm{t} \cdot \mathrm{h}^{-1}\right)$ (Promagri, Casablanca, Casablanca-Settat, Morocco) and Jounes mod. Atila $\left(0.69 \mathrm{t} \cdot \mathrm{h}^{-1}\right)$ (Jonues I Fills Sl, Lleida, Catalonia, Spain), both fed using a pick-up header and discharging into a trailer, tested by Velazquez-Martı et al. [40], as well as a self-propelled Favaretto mod. Speedy cut $\left(0.72 \mathrm{t}_{\mathrm{fm}} \cdot \mathrm{h}^{-1}\right)$ [8], achieved lower productivities than the Facma Combi TR200. In contrast, the SAT-4 and Jordan presented better performances for this variable with $6.01 \mathrm{t} \mathrm{fm}_{\mathrm{m}} \cdot \mathrm{h}^{-1}$ and $6.7 \mathrm{t}_{\mathrm{fm}} \cdot \mathrm{h}^{-1}$, respectively. Finally, Suardi et al. [43] reported a very high material capacity of $7.26 \mathrm{t}_{\mathrm{fm}} \cdot \mathrm{h}^{-1}$ with a Caravaggi Bio900 stationary chipper.

An overall view of the comparison between the results of this study and other similar studies is given in Table 7. It is important to note that the studies about the working productivity of a machine are strongly linked to the context in which the tests were conducted (biomass amount, wheater conditions, slope, skill of the operators, etc.). Therefore, this table is reported to give an overall view of the productivity of some machinery and systems for pruning harvesting, but it does not represent a way to indicate which machine or system is better than the others. 
Table 7. Comparisons between the field capacity and the material capacity of the Facma Comby TR200 and other machines for olive pruning harvesting.

\begin{tabular}{cccc}
\hline Machine & Reference & Field Capacity $\left(\mathbf{h a} \cdot \mathbf{h} \mathbf{- 1}^{\mathbf{1}}\right)$ & Material Capacity $\left(\mathbf{t}_{\mathbf{f m}} \cdot \mathbf{h}^{\mathbf{- 1})}\right.$ \\
\hline Facma Comby TR200 FL & This study & 1.57 & 3.56 \\
Facma Comby TR200 HL & This study & 0.79 & 3.75 \\
Favaretto Speedy Cut & {$[8]$} & 0.39 & 0.72 \\
SAT-4 & {$[8]$} & 3.37 & 6.01 \\
Jordan & {$[8]$} & 0.60 & 6.70 \\
Serrat Olipack T1800 & {$[40]$} & 0.78 & 1.38 \\
Berti Picker C180 & {$[40]$} & 0.85 & 1.26 \\
Promagri 2000 & {$[40]$} & n.d. & 1.36 \\
Jounes Atila & {$[40]$} & n.d. & 0.69 \\
Tierre Plano & {$[41]$} & 0.85 & 11.00 \\
Nobili TRP-RT 145 & {$[42]$} & n.d. & 0.53 \\
Caravaggi BIO900 & {$[43]$} & 0.60 & 7.26 \\
\hline
\end{tabular}

After giving an overall evaluation of the machine, it is possible to say that the Facma Comby TR200 showed good productivity, which was generally higher than other shredders in the market. However, from the obtained results, it is possible to notice the substantial influence of biomass yield on work productivity. In fact, the HL field showed a value that was approximately twice the FL value, thus allowing for a higher material capacity even with a lower field capacity. The same trend was also found in Spinelli and colleagues [8,39].

\subsection{Cost Analysis}

Comparing this paper's results on cost analysis with the previously mentioned studies [8,39], it is possible to notice the interesting economic performance of the Facma Comby TR200. Taking into consideration the costs per fresh biomass unit $\left(\mathrm{t}_{\mathrm{fm}} \mathrm{ha}^{-1}\right)$, the Facma Comby TR200 on the hilly slope (HL) showed the best economic performance with $16.59 € \cdot \mathrm{t}_{\mathrm{fm}}{ }^{-1}$. For the flat slope (FL), the Facma Comby TR200 had an economic performance of $29.88 € \cdot \mathrm{t}_{\mathrm{fm}}{ }^{-1}$; a similar performance was found by Spinelli et al. [39] for a Jordan machine with $22.53 € \cdot \mathrm{t}_{\mathrm{fm}}{ }^{-1}$ and a SAT-4 with $29.99 € \cdot \mathrm{t}_{\mathrm{fm}}{ }^{-1}$. Substantially higher costs were found by Spinelli et al. [8] for a Favaretto Speedy Cut $\left(58.70 € \cdot \mathrm{t}_{\mathrm{fm}}{ }^{-1}\right)$, although it carried out two phases (pruning and harvesting of pruning) in a single phase.

A key aspect to be taken into consideration for properly assessing and evaluating the economic performance of a pruning harvesting system is the economic profitability of these, which can be obtained by subtracting the harvesting costs from the revenue earned at the market price of hog fuel. The main problem in doing this is linked to the difficulties in the determination of the hog fuel price, which is even more complex in Mediterranean areas, e.g., in Greece, since there is not even a market for wood chips and much less one for hog fuel [44].

For this reason, a "revenue-costs" analysis of FL and HL was attempted by referring to Central and South Italy's hog fuel prices. This context is very similar to Greece regarding the spread of olive groves and the problems linked to the pruning's residues value chain. Even in Italy, it is not simple to find information on the hog fuel price; therefore, the authors performed a personal market analysis by interviewing various enterprises and cooperatives involved in the residual biomass value chain. The results of the interviews were very interesting and fundamental for implementing the economic analysis. The first aspect highlighted by the interviews was that the wood chips or hog fuel price, conferred to biomass power plants, is strongly influenced by the contract between the plant and the enterprise that gives the wooden material; therefore, the biomass quality, which is indeed fundamental, is not the only variable to take into consideration. In particular, power plants pay the highest price to big farmers with long-duration conferring contracts but they pay substantially lower prices to little farmers that have no contract and that only bring material to the plant occasionally. In more detail, hog fuel prices range from $25 € \cdot \mathrm{t}^{-1}$ (small producer with no contract with the biomass 
plant) to $40 € \cdot \mathrm{t}^{-1}$ (big enterprises with long-lasting conferring contracts). These prices are referred to as the landing sites of biomass, but in the case where the producer brings the hog fuel to the plant themselves, the prices are generally $10 € \cdot \mathrm{t}^{-1}$ higher. According to this, to create an efficient value chain for hog fuel from pruning residues, it is important not only the increase the obtained biomass quality, as mentioned above, but also to create cooperatives or consortia among various farmers, allowing them to have better contracts with biomass plants. On the other hand, another possible solution is the development of energetic micro-chains using pruning residues not for selling them to big plants, but for the development of small heating systems for the farm premises.

Considering the complexity of this sector's market, another important and interesting approach is that of Fiusis's power plant (Calimera, Apulia, Italy). This company manages a biomass power plant in the Apulia region (Italy) and also developed a controlled enterprise for pruning harvesting and biomass supply. In detail, the owners of olive groves who want to give pruning residues to Fiusis only have to rake the biomass and then Fiusis handles the biomass harvesting without paying anything to the farmer; the farmer has the advantage of having pruning's residues removed from the field and incurring only raking costs. Such an approach could also be successful in other countries and productive contexts.

Another important aspect to be underlined, which was already reported in the previous paragraph dealing with the work productivity analysis, is the significant influence of biomass yield on machine performance, and consequently, on economic performance.

This aspect is shown in Figure 5. By considering the results of the costs analysis per surface unit area $\left(€ \cdot \mathrm{ha}^{-1}\right)$ and a hog fuel price of $25 € \cdot \mathrm{t}^{-1}, 2.7 \mathrm{t}_{\mathrm{fm}} \cdot \mathrm{ha}^{-1}$ and $3.3 \mathrm{t}_{\mathrm{fm}} \cdot \mathrm{ha}^{-1}$ are needed to obtain economic balance from FL and $\mathrm{HL}$, respectively. Considering instead a hog fuel price of $40 € \cdot \mathrm{t}^{-1}, 1.7 \mathrm{t} \mathrm{fm}_{\mathrm{fm}} \cdot \mathrm{ha}^{-1}$ and $2.1 \mathrm{t}_{\mathrm{fm}} \cdot \mathrm{ha}^{-1}$ are necessary from FL and HL, respectively.

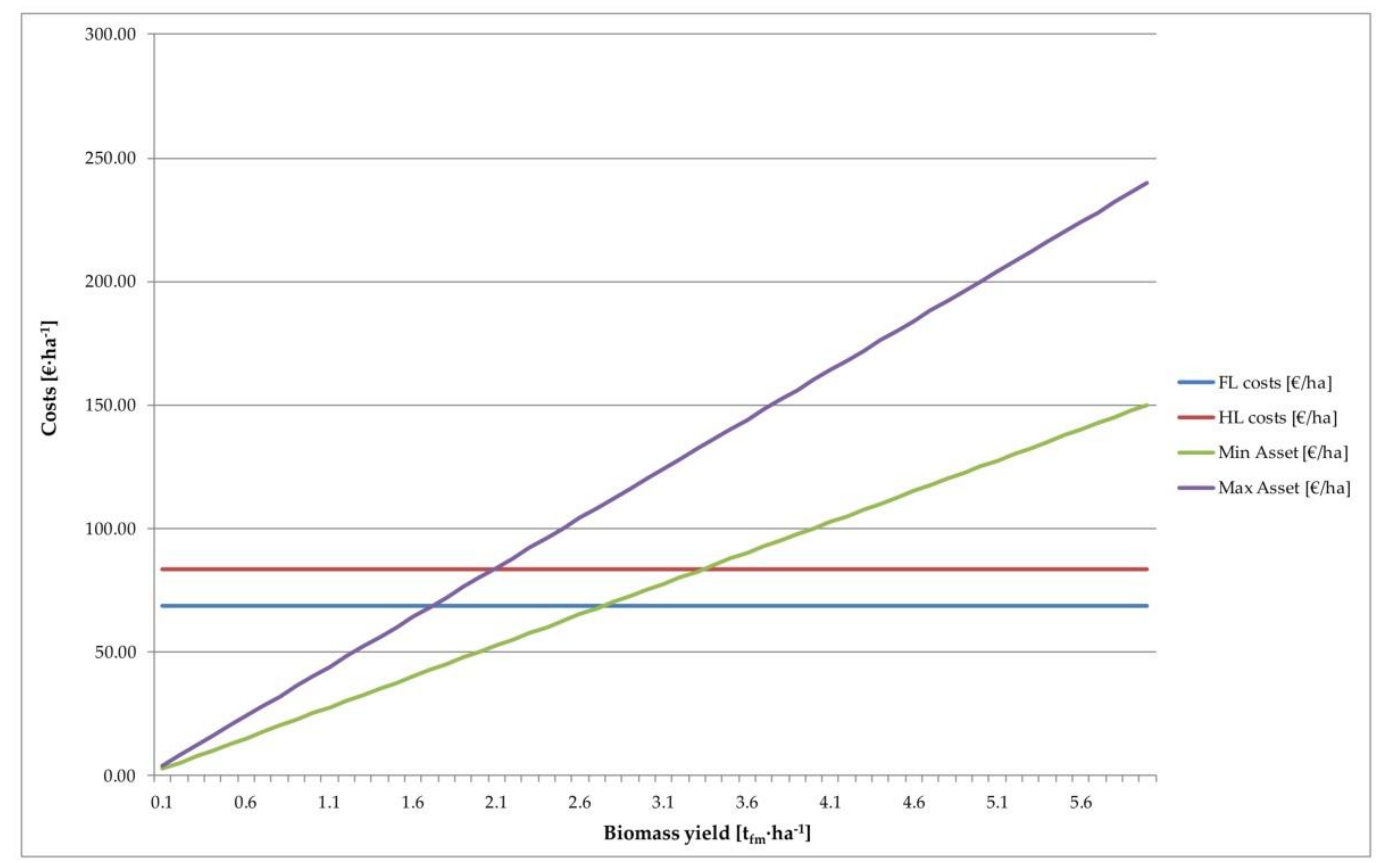

Figure 5. Relation between the biomass yield and economic profitability by considering a minimum price for hog fuel of $25 € \cdot \mathrm{t}^{-1}$ (green line) and a maximum one of $40 € \cdot \mathrm{t}^{-1}$ (purple line). The intersections with the blue (FL) and red (HL) lines indicate the minimum biomass yield necessary to achieve an economic balance from pruning harvesting by considering the costs per surface unit $\left(€ \cdot \mathrm{ha}^{-1}\right)$ for FL and HL.

Focusing on this paper's results regarding costs per fresh biomass unit $\left(€ \cdot \mathrm{t}_{\mathrm{fm}}{ }^{-1}\right)$ and taking into consideration the minimum price for hog fuel, i.e., $25 € \cdot \mathrm{t}^{-1}$, it is found that only HL was cost-effective 
with a positive balance of $+8.41 € \cdot t_{\mathrm{fm}}{ }^{-1}$; on the other hand, FL was not cost-effective, showing a negative balance of $-4.88 € \cdot \mathrm{t}_{\mathrm{fm}}{ }^{-1}$. Considering instead the higher price for hog fuel $\left(40 € \cdot \mathrm{t}^{-1}\right)$, both FL and HL showed positive balances with $+23.41 € \cdot t_{\mathrm{fm}}{ }^{-1}$ and $+10.12 € \cdot \mathrm{t}_{\mathrm{fm}}{ }^{-1}$, respectively.

The last aspect to be discussed is about the improvement possibilities of the investigated harvesting system. As previously reported, the first issue is limiting rocks and soil contamination using a correct setting of the pick-up height and through the application of dedicated screens. Moreover, using a smaller tractor to power the Facma Comby TR200 seems to be a better solution, considering that this machine needed only $55 \mathrm{~kW}$ of tractor power take-off. The Ebro model 85 used in the tests was consistently oversized and using a smaller tractor, e.g., a $66 \mathrm{~kW}$ one, could lead to a lower turning time within the olive grove, thus allowing for a higher field capacity, and also a reduced fuel consumption. This is particularly true for this particular pruning harvesting operation, where the working speed was mostly linked to the towed shredder and not to the tractor itself. Thus a more powerful tractor does not generally lead to a higher working speed but only to a higher fuel consumption and (most likely) to higher turning times.

\section{Conclusions}

In summary, hills with a slope not exceeding $25 \%$ seemed to not be an important limit for the Facma Comby TR200 in terms of performance and fuel consumption. In fact, the machine showed good work performances on both flat and hilly slopes, which were often higher than the ones recorded by other authors with other harvesting systems. The worst aspects were represented by biomass losses and the characteristics of the comminuted material, in particular, the unacceptably high ash content. To improve these aspects, some modifications to the shredder's pick-up systems (e.g., swath brushes) seem necessary.

Finally, the economic aspects of this study's results were in line with those reported in the literature. Furthermore, it was concluded that the biomass yield had a significant influence on the machine performance, and consequently, on the economic sustainability of the harvesting phase. To obtain an efficient chain for hog fuel derived from olive groves' pruning, as well as improving the working phase, the development of consortia or a cooperative between the various farmers could be a positive solution, which would allow for obtaining higher prices from biomass plants.

Author Contributions: Conceptualization: A.S., L.P., and F.L.; methodology: A.S. and V.A.; validation: L.P., data curation: A.S., V.A., and S.B.; writing—original draft preparation: F.L.; writing—review and editing: A.S., F.L., E.K., M.A.K., N.P., and P.G.; supervision: A.S. and L.P.; funding acquisition: L.P. and E.K. All authors have read and agreed to the published version of the manuscript.

Funding: This work was performed under the framework of the European project AGROinLOG "Demonstration of innovative integrated biomass logistics centres for the Agro-industry sector in Europe." This project received funding from the European Union's Horizon 2020 research and innovation program under grant agreement no. 727961. The information and views set out in this paper are those of the authors and do not necessarily reflect the official opinion of the European Union. Neither the European Union institutions and bodies, nor any person acting on their behalf, may be held responsible for the use that may be made of the information contained therein.

Acknowledgments: The authors wish to thank Fiusis (Calimera, LE, Italy) for providing data. Furthermore, the authors would like to thank the Agriculture Cooperative of Agios Konstantinos-Lokridas, INASO-PASEGES and NUTRIA for contributing to the successful monitoring of the harvesting demonstration in Agios Konstantinos.

Conflicts of Interest: The authors declare no conflict of interest. The funders had no role in the design of the study; in the collection, analyses, or interpretation of data; in the writing of the manuscript, or in the decision to publish the results. 


\section{Abbreviations:}

$\begin{array}{ll}\text { IBLC } & \text { Integrated biomass logistics center } \\ \text { NUTS } & \text { Nomenclature of Territorial Units for Statistics in Greece } \\ \text { FL } & \text { Flat slope experimental field } \\ \text { HL } & \text { Hilly slope experimental field } \\ \text { TFC } & \text { Theoretical field capacity }\left(\mathrm{ha} \cdot \mathrm{h}^{-1}\right) \\ \text { EFC } & \text { Effective field capacity }\left(\mathrm{ha} \cdot \mathrm{h}^{-1}\right) \\ \text { OT } & \text { Operating time }(\mathrm{h}) \\ \text { MC } & \text { Material capacity }\left(\mathrm{t} \cdot \mathrm{h}^{-1}\right) \\ \text { PSD } & \text { Particle size distribution } \\ \text { HHV } & \text { Higher heating value }\left(\mathrm{MJ} \cdot \mathrm{kg}^{-1}\right) \\ \text { CRPA } & \text { Centro Ricerca per le Produzioni Animali } \\ \text { CERTH } & \text { The Centre for Research \& Technology, Hellas } \\ \text { CPERI } & \text { Chemical Process Engineering Research Institute } \\ \text { FM } & \text { Fresh matter } \\ \text { DM } & \text { Dry matter } \\ \text { INASO-PASEGES } & \text { Institouto Agrotikis kai Sinetairistikis Oikonomias } \\ \text { NUTRIA } & \text { NUTRIA S.A., Agios Kostantinos, Fthiotida, Greece }\end{array}$

\section{References}

1. Talbert, R.J.A. Atlas of Classical History; Routledge: Milton Park, UK, 2002; ISBN 1134966539.

2. Lu, L.; Tang, Y.; Xie, J.; Yuan, Y. The role of marginal agricultural land-based mulberry planting in biomass energy production. Renew. Energy 2009, 34, 1789-1794. [CrossRef]

3. Torquati, B.; Marino, D.; Venanzi, S.; Porceddu, P.; Chiorri, M. Using tree crop pruning residues for energy purposes: A spatial analysis and an evaluation of the economic and environmental sustainability. Biomass Bioenergy 2016, 95, 124-131. [CrossRef]

4. Akhmedov, S.; Ivanova, T.; Abdulloeva, S.; Muntean, A.; Krepl, V. Contribution to the Energy Situation in Tajikistan by Using Residual Apricot Branches after Pruning as an Alternative Fuel. Energies 2019, 12, 3169. [CrossRef]

5. Alatzas, S.; Moustakas, K.; Malamis, D.; Vakalis, S. Biomass Potential from Agricultural Waste for Energetic Utilization in Greece. Energies 2019, 12, 1095. [CrossRef]

6. García-Galindo, D.; Dyjakon, A.; Cay Villa-Ceballos, F. Building Variable Productivity Ratios for Improving Large Scale Spatially Explicit Pruning Biomass Assessments. Energies 2019, 12, 957. [CrossRef]

7. Dyjakon, A. The influence of apple orchard management on energy performance and pruned biomass harvesting for energetic applications. Energies 2019, 12, 632. [CrossRef]

8. Spinelli, R.; Magagnotti, N.; Nati, C.; Cantini, C.; Sani, G.; Picchi, G.; Biocca, M. Integrating olive grove maintenance and energy biomass recovery with a single-pass pruning and harvesting machine. Biomass Bioenergy 2011, 35, 808-813. [CrossRef]

9. Gasol, C.M.; Gabarrell, X.; Rigola, M.; González-García, S.; Rieradevall, J. Environmental assessment:(LCA) and spatial modelling (GIS) of energy crop implementation on local scale. Biomass Bioenergy 2011, 35, 2975-2985. [CrossRef]

10. Dyjakon, A.; García-Galindo, D. Implementing agricultural pruning to energy in europe: Technical, economic and implementation potentials. Energies 2019, 12, 1513. [CrossRef]

11. Pari, L.; Suardi, A.; Frąckowak, P.; Adamczyk, F.; Szaroleta, M.; Santangelo, E.; Bergonzoli, S.; Del Giudice, A.; Dyjakon, A. Two innovative prototypes for collecting pruning biomass: Early performance tests and assessment of the work quality. Biomass Bioenergy 2018, 117, 96-101. [CrossRef]

12. Ghaderi, H.; Pishvaee, M.S.; Moini, A. Biomass supply chain network design: An optimization-oriented review and analysis. Ind. Crop. Prod. 2016, 94, 972-1000. [CrossRef]

13. Pari, L.; Suardi, A.; Santangelo, E.; García-Galindo, D.; Scarfone, A.; Alfano, V. Current and innovative technologies for pruning harvesting: A review. Biomass Bioenergy 2017, 107, 398-410. [CrossRef] 
14. Agroinlog Integrated Biomass Logistic Centres for the Agro-industry. EU Horizon 2020 Research and Innovation Programme-Grant Agreement No 727961. Available online: http://agroinlog-h2020.eu/en/home/ (accessed on 14 February 2020).

15. Annevelink, B.; Van Gogh, B.; Nogués, F.S.; Espatolero, S.; De La Cruz, T.; Luzzini, D.; Karampinis, M.; Kougioumtzis, M.; Olsson, J. Conceptual description of an integrated biomass logistics centre (IBLC). In Proceedings of the European Biomass Conference and Exhibition Proceedings, Stockholm, Sweden, 12-15 June 2017; Volume 2017, pp. 200-203.

16. Picchi, G.; Spinelli, R. Industrial harvester biomass procurement of olive trees residues. In Proceedings of the 19th Europian Biomass Conference and Exhibition, Berlin, Germany, 6-10 June 2011; pp. 6-10.

17. Manzone, M.; Gioelli, F.; Balsari, P. Effects of Different Storage Techniques on Round-Baled Orchard-Pruning Residues. Energies 2019, 12, 1044. [CrossRef]

18. Dyjakon, A. The influence of the use of windrowers in baler machinery on the energy balance during pruned biomass harvesting in the apple orchard. Energies 2018, 11, 3236. [CrossRef]

19. Acampora, A.; Croce, S.; Assirelli, A.; Del Giudice, A.; Spinelli, R.; Suardi, A.; Pari, L. Product contamination and harvesting losses from mechanized recovery of olive tree pruning residues for energy use. Renew. Energy 2013, 53, 350-353. [CrossRef]

20. Civitarese, V.; Del Giudice, A.; Suardi, A.; Santangelo, E.; Pari, L. Study on the effect of a new rotor designed for chipping short rotation woody crops. Croat. J. For. Eng. J. Theory Appl. For. Eng. 2015, 36, 101-108.

21. Del Giudice, A.; Assirelli, A.; Gallucci, F.; Bellacima, R.; Pari, L.; Santangelo, E. Production of energy feedstock from the riparian vegetation of Arundo donax (L.): Suitability of the chopping systems. Ecol. Eng. 2017, 102, 459-467. [CrossRef]

22. Spinelli, R.; Cavallo, E.; Eliasson, L.; Facello, A. Comparing the efficiency of drum and disc chippers. Silva Fenn. 2013, 47, 1-11. [CrossRef]

23. Abdallah, R.; Auchet, S.; Méausoone, P.J. Experimental study about the effects of disc chipper settings on the distribution of wood chip size. Biomass Bioenergy 2011, 35, 843-852. [CrossRef]

24. Barontini, M.; Scarfone, A.; Spinelli, R.; Gallucci, F.; Santangelo, E.; Acampora, A.; Jirjis, R.; Civitarese, V.; Pari, L. Storage dynamics and fuel quality of poplar chips. Biomass Bioenergy 2014, 62, 17-25. [CrossRef]

25. Nati, C.; Boschiero, M.; Picchi, G.; Mastrolonardo, G.; Kelderer, M.; Zerbe, S. Energy performance of a new biomass harvester for recovery of orchard wood wastes as alternative to mulching. Renew. Energy 2018, 124, 121-128. [CrossRef]

26. Nati, C.; Spinelli, R.; Fabbri, P. Wood chips size distribution in relation to blade wear and screen use. Biomass Bioenergy 2010, 34, 583-587. [CrossRef]

27. Spinelli, R.; Magagnotti, N.; Nati, C.; Pari, L.; Vanneste, J.L. Recovering kiwifruit pruning residues for biomass production. Trans. ASABE 2012, 55, 21-28. [CrossRef]

28. Jones, T.G.; Song, G.G.; Richardson, J.D. Effect of chipper setting on chip size distribution and mechanical pulp properties. Appita Technol. Innov. Manuf. Environ. 2005, 58, 56.

29. Hellenic Statistical Authority (ELSTAT). Annual Agricultural Statistical Survey: 2015. Available online: Www.statistics.gr (accessed on 10 January 2020).

30. Kougioumtzis, M.-A.; Karampinis, E.; Grammelis, P.; Kakaras, E. Assessment of biomass resources for an integrated biomass logistics center (IBLC) operating in the olive oil sector. In Proceedings of the European Biomass Conference and Exhibition Proceedings, Copenhagen, Denmark, 14-17 May 2018; Volume 2018, pp. 309-313.

31. ASAE. ASAE S495 Uniform Terminology for Agricultural Machinery Management. Society 2000, 342-343.

32. EN ISO 18134-2:2017. Solid Biofuels—Determination of Moisture Content—Oven Dry Method—Part 2: Total Moisture-Simplified Method. Available online: https://www.iso.org/standard/71536.html (accessed on 15 March 2020).

33. ISO 17828:2015. Solid Biofuels—Determination of Bulk Density. 2015; Available online: https://www.iso.org/ obp/ui/\#iso:std:iso:17828:ed-1:v1:en (accessed on 15 March 2020).

34. ISO 17225-4:2014. Solid Biofuels_Fuel Specifications and Classes_Part 4: Graded Wood Chips. Available online: https://www.iso.org/standard/59459.html (accessed on 15 March 2020).

35. ISO 18122:2015. Solid Biofuels—Determination of Ash Content. Available online: https://www.iso.org/obp/ ui/\#iso:std:iso:18122:ed-1:v1:en (accessed on 15 March 2020).

36. ISO 18125:2015. Solid Biofuels-Determination of the Gross Calorific Value. 
37. Assirelli, A.; Pignedoli, S. Costo di esercizio delle macchine agricole. Cent. Ric. Prod. Anim. 2005, 5, 1-10.

38. Picchi, G.; Lombardini, C.; Pari, L.; Spinelli, R. Physical and chemical characteristics of renewable fuel obtained from pruning residues. J. Clean. Prod. 2018, 171, 457-463. [CrossRef]

39. Spinelli, R.; Picchi, G. Industrial harvesting of olive tree pruning residue for energy biomass. Bioresour. Technol. 2010, 101, 730-735. [CrossRef]

40. Velázquez-Martí, B.; Fernández-González, E. Analysis of the process of biomass harvesting with collecting-chippers fed by pick up headers in plantations of olive trees. Biosyst. Eng. 2009, 104, 184-190. [CrossRef]

41. Assirelli, A.; Croce, S.; Acampora, A. Potature di olivo da energia le trinciacaricatrici più adatte. L'Informatore Agrario 2012, 25, 32-36.

42. Recchia, L.; Daou, M.; Rimediotti, M.; Cini, E.; Vieri, M. New shredding machine for recycling pruning residuals. Biomass Bioenergy 2009, 33, 149-154. [CrossRef]

43. Suardi, A.; Latterini, F.; Alfano, V.; Palmieri, N.; Bergonzli, S.; Pari, L. Analysis of the Work Productivity and Costs of a Stationary Chipper Applied to the Harvesting of Olive Tree Pruning for Bio-Energy Production. Energies 2020, 13, 1359. [CrossRef]

44. Prislan, P.; Krajnc, N.; Jemec, T.; Piškur, M. Monitoring of wood fuel prices in Slovenia, Austria, Italy, Croatia, Romania, Germany, Spain and Ireland. In Biomass Trade Center II Project, Wood Fuel Prices Report; Findings of Biomass Trade Center II Project; Biomass Trade Center, 2014.

(C) 2020 by the authors. Licensee MDPI, Basel, Switzerland. This article is an open access article distributed under the terms and conditions of the Creative Commons Attribution (CC BY) license (http://creativecommons.org/licenses/by/4.0/). 